\title{
Implementasi Pemenuhan Hak Pendidikan untuk Anak Pidana di Lembaga Pembinaan Khusus Anak Kutoarjo
}

\author{
Farrah Syamala Rosyda \\ Universitas Islam Negeri Sunan Kalijaga, Yogyakarta, Indonesia \\ *email: farrah.rosyda@uin-suka.ac.id
}

DOI: https://doi.org/10.37729/amnesti.v2i1.651

Submitted: November 2019 Revised: Desember 2019 Accepted:Januari 2020

\begin{tabular}{|c|c|}
\hline & ABSTRAK \\
\hline $\begin{array}{l}\text { Kata Kunci: } \\
\text { Hak Pendidikan, } \\
\text { Anak Pidana, } \\
\text { Lembaga } \\
\text { Pembinaan } \\
\text { Khusus Anak }\end{array}$ & $\begin{array}{l}\text { Hak anak salah satunya adalah hak pendidikan. Hak ini tetap } \\
\text { melekat pada anak meskipun anak sedang dihadapkan dengan } \\
\text { proses hukum atau pemidanaan dalam hal ini disebut anak pidana. } \\
\text { Pendidikan juga merupakan salah satu bentuk pembinaan di LPKA } \\
\text { sebagai upaya pembinaan dan persiapan masa depan bagi anak } \\
\text { pidana. Tujuan adanya penelitian ini adalah untuk mengetahui } \\
\text { penerapan hak pendidikan untuk anak pidana dilihat dari bentuk- } \\
\text { bentuk dan prosesnya di Lembaga Pemasyarakatan khususnya di } \\
\text { Lembaga Pembinaan Khusus Anak Kutoarjo. Penelitian ini } \\
\text { diharapkan memberikan kontribusi terkait implementasi hak } \\
\text { pendidikan untuk anak pidana di LPKA yang akan dipublikasikan } \\
\text { ke dalam jurnal ilmiah nasional dan buku ajar. Penelitian ini } \\
\text { menggunakan metode penelitian normatif empiris yaitu } \\
\text { menggunakan data primer dan data sekunder. Data primer } \\
\text { diperoleh dengan cara observasi dan wawancara di Lembaga } \\
\text { Pembinaan Khusus Anak Kutoarjo sebagai satu-satunya lembaga } \\
\text { pemasyarakatan khusus anak yang ada di Jawa Tengah. Data } \\
\text { sekunder didapatkan dari berbagai peraturan perundang- } \\
\text { undangan dan bahan pustaka yang terkait. Data-data yang } \\
\text { diperoleh selanjutnya dianalisis menggunakan metode kualitatif } \\
\text { untuk menjawab rumusan masalah. Hak pendidikan diberikan } \\
\text { dalam bentuk pembinaan kepribadian, pembinaan keterampilan } \\
\text { dan pendidikan anak. Berbagai hak pendidikan diberikan dengan } \\
\text { kerjasama berbagai instansi seperti dinas pendidikan, dinas sosial, } \\
\text { kementerian agama dan lain sebagainya. Proses pemberian hak }\end{array}$ \\
\hline
\end{tabular}


pendidikan diberikan pada tahap pembinaan awal di LPKA Kutoarjo.

$\begin{array}{ll}\begin{array}{l}\text { Keywords: } \\ \text { The Right }\end{array} & \text { ABSTRACT of the rights of children is the right to education. Even if the child is } \\ \text { Education, The } & \text { facing a legal process or punishment, this right still belongs to the child } \\ \text { Criminal } & \text { and is called a criminal child. Education is also a form of coaching at } \\ \text { Children, Special } & \text { LPKA to develop and prepare for the future of criminal children. The } \\ \text { Building } & \text { purpose of this research is to determine the implementation of the right to } \\ \text { Institutions of } & \text { education for criminal children seen from the forms and processes in the } \\ \text { Children } & \text { Correctional Institution, especially in the Kutoarjo Child Special Guidance } \\ & \text { Institute. This research is expected to contribute to implementing the right } \\ & \text { to education for criminal children in LPKA, published in national } \\ \text { scientific journals and textbooks. This study uses empirical normative } \\ \text { research methods, namely using primary data and secondary data. } \\ \text { Primary data was obtained through observation and interviews at the } \\ \text { Kutoarjo Child Special Guidance Institute as the only special child } \\ \text { correctional institution in Central Java. Secondary data is obtained from } \\ \text { various laws and regulations and related library materials. The data } \\ \text { obtained were then analyzed using qualitative methods to answer the } \\ \text { formulation of the problem. The right to education is given in personality } \\ \text { development, skills development and children's education. Various } \\ \text { educational rights are granted in collaboration with various agencies such } \\ \text { as the education office, social service, ministry of religion, etc. The process } \\ \text { of granting education rights is given at the initial coaching stage at LPKA } \\ \text { Kutoarjo. }\end{array}$

\section{PENDAHULUAN}

Anak merupakan aset generasi mendatang yang sangat berharga dan dapat dikatakan bahwa baik buruknya hari depan sebuah bangsa ditentukan oleh tangan-tangan pengembannya (Tatik Mei Widari, 2012). Anak sebagai sumber daya manusia dan merupakan generasi penerus bangsa selayaknya mendapatkan perhatian khusus dari pemerintah, dalam rangka pemenuhan pendidikan untuk mewujudkan sumber daya manusia yang berkualitas dan berkarakter. Berkaitan dengan pemenuhan hak mendapatkan pendidikan dan pembinaan anak, diperlukan sarana dan prasarana hukum yang mengantisipasi segala permasalahan yang timbul. Hal tersebut tidak hilang meskipun seorang anak dihadapkan dengan hukum atau yang biasa disebut dengan anak pidana.

Anak yang berada di lembaga pemasyarakat akan berada dalam lingkungan pengaruh serta perilaku orang-orang yang ada dalam lembaga pemasyarakatan tersebut. Umumnya orang yang berada di dalam lembaga pemasyarakatan tutur katanya kasar, hidupnya keras, dan seringkali 
mengabaikan etika dan budaya serta tata pergaulan yang baik. Anak ketika masuk dalam proses pemidanaan tentu akan memasuki suatu lingkungan yang berbeda dengan lingkungan tempat tinggalnya (orang tua) (Tatilu, 2015).

Pendidikan merupakan syarat pembinaan sebagai upaya pemberian pembelajaraan dan persiapan untuk masa depan narapidana khususnya anak pidana. Hal tersebut dijelaskan Pasal 31 ayat (1) Undang-Undang Dasar Negara Republik Indonesia Tahun 1945 yang berupaya memberikan jaminan bagi setiap warga negaranya untuk memperoleh haknya atas pendidikan. Kemudian pada ayat (2) menyebutkan bahwa setiap warga negara wajib mengikuti pendidikan dasar dan pemerintah wajib membiayainya. Undang-undang Nomor 12 Tahun 1995 Tentang Pemasyarakatan Pasal 22 ayat (1), Peraturan Pemerintah Nomor 32 Tahun 1999 Tentang Syarat Dan Tata Cara Pelaksanaan Warga Binaan Pemasyarakatan Pasal 1 ayat (3), Undang-undang Nomor 11 Tahun 2012 Tentang Sistem Peradilan Pidana Anak Pasal 85 berdasarkan Bab III huruf G tentang Tugas dan Wewenang Kementerian Pendidikan Nasional Lampiran Peraturan Menteri Negara Pemberdayaan Perempuan dan Perlindungan Anak Nomor 15 Tahun 2010 tentang Pedoman Umum Penanganan Anak yang Berhadapan dengan Hukum, Kemudian didalam Undang-Undang Nomor 39 Tahun 1999 tentang Hak Asasi Manusia pada Pasal 60 ayat (1) menyebutkan bahwa setiap anak berhak untuk memperoleh pendidikan dan pengajaran dalam rangka pengembangan pribadinya sesuai dengan minat, bakat dan tingkat kecerdasannya (Hartono, 2019).

Peraturan diatas hanyalah sebuah aturan jika tidak diaplikasikan di lembaga pembinaan khusus anak (LPKA). Namun hal tersebut menimbulkan dinamika dan permasalahan mengingat banyaknya anak dari berbagai usia dan latar belakang pendidikan yang masuk dalam LPKA. Berdasarkan permasalahan tersebut, perlu adanya penelitian mengenai penerapan hak pendidikan sebagai solusi penerapan hak pendidikan yang sesuai dengan kebutuhan anak pidana dan kondisi sarana prasarana di LPKA.

\section{METODE PENELITIAN}

Metode penelitian yang digunakan adalah normatif empiris yang menggabungkan dua data yaitu data primer yang berupa wawancara dan data sekunder berupa data- data pustaka. Penelitian ini menggunakan pendekatan perundang-undangan. Pendekatan perundang-undangan (statute approach) 
yaitu pendekatan dengan menggunakan legislasi dan regulasi. Penelitian ini menelaah peraturan perundang-undang mengenai pembinaan narapidana (anak pidana) melalui pendidikan dan sejauh mana penerapan peraturan tersebut di lembaga pembinaan khusus anak. Lokasi penelitian dilakukan di Lembaga Pembinaan Khusus Anak Kutoarjo. Lembaga pembinaan ini merupakan lembaga pembinaan khusus anak satu-satunya di Provinsi Jawa Tengah.

\section{HASIL DAN PEMBAHASAN}

\subsection{Hak-Hak Anak}

\section{Hak Asasi Manusia}

Hak asasi manusia berasal dari bahasa perancis yaitu Droits L'Homme yang mempunyai arti hak- hak manusia, sedangkan dalam bahasa inggris adalah Human Rights dan Bahasa Belanda adalah Menselijke Rechten. Terdapat dua pengertian dasar dari hak asasi manusia, yaitu hak alamiah manusia yang dimiliki sejak manusia lahir yang bersumber dari moral manusia dan hak-hak manusia yang berdasarkan aturan hukum (Ni Ketut Sri Utari, 2016).

Berdasarkan UU No. 39 Tahun 1999 tentag Hak Asasi Manusia Pasal 1 ayat (1), pengertian Hak asasi manusia adalah:

"Seperangkat hak yang melekat pada hakikat dan keberadaan manusia sebagai mahkluk Tuhan Yang Maha Esa dan merupakan anugerah-Nya yang wajib dihormati, dijunjung tinggi dan dilindungi oleh negara, hukum, Pemerintah, dan setiap orang demi kehormatan serta perlindungan harkat dan martabat manusia".

Menurut Osita Oze, Hak asasi manusia adalah tuntutan individu atau kelompok kepada masyarakat atau negara. Tututan tersebut ada yang dijamin serta dilindungi oleh hukum namun ada juga yang menjadi harapan dimasa depan (Halili, 2015). Pengertian tersebut menjelaskan bahwa tidak sepenuhnya hak asasi manusia dilindungi sepenuhnya oleh negara, namun terdapat yang perlu diperjuangkan oleh individu atau kelompok tersebut. Terdapat 2 (dua) unsur utama dalam pengertian hak asasi manusia yaitu:

1. Hak tersebut ada sebelum adanya ketetapan dari negara

2. Hak tersebut bersifat universal tanpa melihat asal usul, warna kulit, latar belakang dan lain sebagainya. 
Bentuk-bentuk hak asasi manusia berdasarkan UU No. 39 Tahun 1999 tentang Hak Asasi Manusia adalah:

a. Hak untuk hidup

b. Hak berkeluarga dan melanjutkan keturunan

c. Hak mengembangkan diri

d. Hak memperoleh keadilan

e. Hak atas kebebasan pribadi

f. Hak atas rasa aman

g. Hak atas kesejahteraan

h. Hak turut serta dalam pemerintahan

i. Hak wanita

j. Hak anak

\section{Pengertian Hak Anak}

Berbicara tentang masalah anak, tentunya membahas mengenai hak dan kewajiban anak. Di Indonesia, pengatuan mengenai hak anak diatur dalam UU No 39 Tahun 1999, UU No. 23 Tahun 2002 tentang Perlindungan Anak dan Keputusan Presiden No. 36 Tahun 1990 tentang Pengesahan Konvensi Hak-Hak Anak. Pengertian hak anak dalam UU No. 39 Tahun 1999 tercantum dalam Pasal 52 menjelaskan bahwa hak anak merupakan bagian dari hak asasi manusia yang diakui dan dilindungi hukum sejak anak tersebut dalam kandungan. Hak anak menurut UU No. 23 Tahun 2002 tentang Perindungan Anak adalah bagian dari hak asasi manusia yang dijamin, dilindungi, dan dipenuhi oleh orang tua, keluarga, masyarakat, pemerintah dan negara. Hak anak dapat dikelompokkan dalam 4 kategori menurut konvensi hak anak hak anak yaitu: hak untuk kelangsungan hidup, hak untuk tumbuh kembang, hak untuk perlindungan dan hak untuk partisipasi (Setya Wahyudi, 2011).

\section{Hak Pendidikan}

Hak yang dimiliki oleh anak salah satunya adalah hak pendidikan. UUD 1945 mengatur mengenai hak pendidikan didalam Pasal 31 yang menjelaskan bahwa hak setiap warga negara adalah mendapatkan pendidikan dan wajib menjalani pendidikan dasar dan pemerintah wajib membiayainya. Selain dalam UUD 1945, hak pendidikan juga diatur dalam deklarasi hak anak dalam asas. Hak pendidikan dalam deklarasi hak anak dijelaskan bahwa pendidikan anak harus diperhatikan muai dari orang tua sampai pihak yang terkait dalam hal 
ini pemerintah agar hak pendidikan tersebut dapat terpenuhi (Wagiati Soetodjo, 2010).

Pasal 60 UU no 39 tahun 1999 Berdasarkan konvensi hak anak, hak pendidikan masuk dalam kategori hak untuk tumbuh kembang. Pada dasarnya hak untuk tumbuh kembang adalah mendapatkan hak pendidikan dalam segala bentuk pendidikan dan taraf hidup anak untuk pengembangan fisik, mental, spiritual, moral dan sosial anak. Pendidikan menjadi salah satu upaya untuk membimbing ke arah tujuan yang tinggi. Tujuan itu dapat tercapai dengan pendidikan yang baik (Syaiful Sagala, 2003). Tujuan yang dimaksud bisa bermacam-macam, salah satunya adalah masa depan yang lebih baik. Pendidikan berisi pengertian yang luas, yaitu terdiri dari pendidikan, pengajaran dan pelatihan. Meskipun bagi orang awam ketiganya dianggap sama artinya, tapi ketiganya memiliki arti yang berbeda. Ketiga istilah tersebut akan lebih jelas jika kita lihat dalam konteks kata kerjanya, yaitu dalam bentuk mendidik, mengajar, dan melatih (Sofi Artnisa Siddiq, 2015).

\subsection{Anak Pidana / Narapidana anak}

\section{Pengertian Anak Pidana}

Tidak sedikit anak harus berhadapan dengan hukum sejak usia yang sangat dini karena melakukan tindak pidana dengan berbagai alasan, dan tidak sedikit juga anak yang harus berakhir memprihatinkan, menghabiskan masa hidupnya di balik tembok penjara, terenggut dari keluarga dan lingkungannya (Septianita, 2018). Anak- anak yang melanggar norma yang hidup dalam masyarakat dan melakukan tindak pidana dikatakan sebagai anak nakal. Bagi anak-anak nakal tersebut bisa dijatuhkan hukuman atau sanksi berupa tindakan atau pidana apabila terbukti melanggar perundang-undangan hukum pidana (Alden Juniedy Simanjuntak et al., 2013). Walaupun demikian hukum harus tetap ditegakkan, meskipun anak yang melakukan tindak pidana mendapat perlindungan hukum oleh undang-undang tidak serta merta luput dari sanksi (Hasibuan et al., 2016). Sanksi pidana diadakan untuk memberikan efek jera bagi para pelaku tindak pidana agar mempertanggungjawabkan akibat dari hasil tidakannya dan tidak mengulangi tindakan tersebut lagi di kemudian hari (Gandhung Wahyu Febrianto Nugroho, 2018).

Pasal 1 angka 8 Undang- Undang Nomor 12 tahun 1995 jo. Pasal 13 PP No. 31 Tahun 1999 tentang Pembinaan Warga Binaan Pemasyarakatan, 
menjelaskan bahwa Anak Pidana, adalah anak berdasarkan putusan pengadilan menjalani pidana di Lapas Anak paling lama sampai berumur 18 (delapan belas) tahun (Maidin Gultom, 2008).

Berdasarkan Pasal 18 ayat (2), anak pidana ditempatkan di Lembaga Pemasyarakatan (Lapas) Anak. Pendaftaran anak pidana dilakukan melalui pencatatan berupa putusan pengadilan, jati diri, barang dan uang yang dibawa, pemeriksaan kesehatan, pembuatan pasfoto, pengambilan sidik jari serta pembuatan berita acara serah terima anak pidana lihat Pasal 19 Undangundang No 12 Tahun 1995. Namun terdapat pembaharuan peraturan perundang- undangan yang khusus menjelaskan mengenai sistem peradilan pidana anak bahwa, anak pidana ditempatkan di Lembaga Pembinaan Khusus Anak Pasal 85 UU No. 11 Tahun 2012 tentang Sistem Peradilan Pidana Anak, Lembaran Negara Republik Indonesia Tahun 2012.

\section{Hak Anak Pidana}

Hak-hak anak pidana diatur dalam Pasal 3 UU No. 11 Tahun 2012 tentang Sistem Peradilan Pidana Anak adalah:

1. Diperlakukan secara manusiawi dengan memperhatikan kebutuhan sesuai dengan umurnya;

2. Dipisahkan dari orang dewasa;

3. Memperoleh bantuan hukum dan bantuan lain secara efektif;

4. Melakukan kegiatan rekreasional;

5. Bebas dari penyiksaan, penghukuman atau perlakuan lain yang kejam, tidak manusiawi, serta merendahkan derajat dan martabatnya;

6. Tidak dijatuhi pidana mati atau pidana seumur hidup;

7. Tidak ditangkap, ditahan, atau dipenjara, kecuali sebagai upaya terakhir dan dalam waktu yang paling singkat;

8. Memperoleh keadilan di muka pengadilan Anak yang objektif, tidak memihak, dan dalam sidang yang tertutup untuk umum;

9. Tidak dipublikasikan identitasnya;

10. Memperoleh pendampingan orang tua/Wali dan orang yang dipercaya oleh Anak;

11. Memperoleh advokasi sosial;

12. Memperoleh kehidupan pribadi;

13. Memperoleh aksesibilitas, terutama bagi anak cacat;

14. Memperoleh pendidikan; 
15. Memperoleh pelayananan kesehatan; dan

16. Memperoleh hak lain sesuai dengan ketentuan peraturan perundangundangan.

Selain dalam UU No. 11 Tahun 2012 tentang Sistem Peradilan Pidana Anak, hak-hak narapidana anak/anak pidana yang tetap dilindungi dalam Sistem Pemasyarakatan Indonesia. Hak-hak pidana diatur oleh Pasal 22 ayat (1) Undang-Undang Nomor 12 Tahun 1995 tentang Pemasyarakatan, sebagai berikut:

1. Melakukan ibadah sesuai agama dan kepercayaannya;

2. Mendapatkan perawatan, baik perawatan rohani maupun perawatan jasmani;

3. Mendapatkan pendidikan dan pengajaran;

4. Mendapatkan pelayanan kesehatan dan makanan yang layak;

5. Menyampaikan keluhan;

6. Mendapatkan bahan bacaan dan mengikuti siaran media massa lainnya yang tidak dilarang;

7. Menerima kunjungan keluarga, penasehat hukum, atau orang tertentu lainnya;

8. Mendapatkan pengurangan masa pidana (remisi);

9. Mendapatkan kesempatan berasimilasi termasuk cuti mengunjungi keluarga;

10. Mendapatkan pembebasan bersyarat;

11. Mendapatkan cuti menjelang bebas;

12. Mendapatkan hak-hak sesuai dengan peraturan perundang- undangan yang berlaku.

Berdasarkan peraturan-peraturan diatas, anak pidana masih mempunyai hak-hak yang harus dipenuhi meskipun sedang menjalani hukumannya. Hak-hak yang masih dimiliki salah satunya adalah hak pendidikan. Dari perspektif hak asasi manusia (HAM), pelaksanaan pendidikan anak termasuk bagi anak didik pemasyarakatan di LPKA secara ideal bersifat non diskriminasi (Budijanto, 2013).

\subsection{Lembaga Pembinaan Khusus Anak}

\section{Pengertian Lembaga Pembinaan Khusus Anak}

Tempat pembinaan narapidana dan anak didik pemasyarakatan berdasarkan UU No. 12 Tahun 1995 tentang Pemasyarakatan berada di 
Lembaga Pemasyarakatan (LAPAS). Pada Tahun 2012 terdapat aturan yang memisahkan tempat pembinaan untuk anak didik pemasyarakatan yaitu di Lembaga Pembinaan Khusus Anak atau di Lembaga Penempatan Anak Sementara lihat Pasal 85 UU No. 11 Tahun 2012 tentang Sistem Peradilan Pidana Anak.

Perbedaan antara Lembaga Pembinaan Khusus Anak dengan Lembaga Penempatan Anak Sementara adalah, Lembaga Pembinaan Khusus Anak merupakan tempat anak menjalani pidananya sedangkan Lembaga Penempatan Anak Sementara merupakan tempat anak saat proses peradilan berlangsung Pasal 1 UU No. 11 Tahun 2012 tentang Sistem Peradilan Pidana Anak. Di Indonesia belum setiap daerah mempunyai Lembaga Pembinaan Khusus Anak (LPKA). Menurut Menteri Hukum dan HAM, di Indonesia baru memiliki 33 LPKA. Di Provinsi Jawa Tengah hanya memiliki satu LPKA yaitu LPKA Kutoarjo.

1. Bentuk Pembinaan di Lembaga Pembinaan Khusus Anak (LPKA) Pasal 5 UU No. 12 Tahun 1995 menjelaskan bahwa sistem pemasyarakatan harus sesuai dengan asas sebagai berikut :
a. Pengayoman
b. persamaan perlakuan dan pelayanan;
c. pendidikan;
d. pembimbingan;
e. penghormatan harkat dan martabat manusia;
f. kehilangan kemerdekaan merupakan satu-satunya penderitaan; dan
g. terjaminnya hak untuk tetap berhubungan dengan keluarga dan orang- orang tertentu.

2. LPKA merupakan salah satu lembaga pemasyarakatan, sehingga LPKA juga tunduk terhadap UU No. 12 Tahun 1995 sebagai aturan yang menjelaskan mengenai pemasyarakatan. Selain peraturan tersebut, terdapat peraturan yang lebih detail menjelaskan mengenai bentuk pembinaan didalam LPKA, yaitu UU No. 11 Tahun 2012 tentang Sistem Peradilan Pidana Anak Pasal 85 ayat (3) dan (4) yang berbunyi:

“(2) Anak sebagaimana dimaksud pada ayat (1) berhak memperoleh pembinaan, pembimbingan, pengawasan, pendampingan, pendidikan dan pelatihan, serta hak lain sesuai dengan ketentuan peraturan perundang-undangan." 
3. LPKA wajib menyelenggarakan pendidikan, pelatihan keterampilan, pembinaan, dan pemenuhan hak lain sesuai dengan ketentuan peraturan perundangundangan.

Penjelasan yang lebih rinci dijelaskan dalam Peraturan Menteri Negara Pemberdayaan Perempuan dan Perlindungan Anak Nomor 15 Tahun 2010 tentang Pedoman Umum Penanganan Anak yang Berhadapan dengan Hukum bab III, yaitu penyelenggaraan proses pendidikan dilakukan berdasarkan proses dan tahap pembinaan pemasyarakatan. Pelaksanaan proses dan tahap pembinaan meliputi tahap admisi- orientasi dan pembinaan pendahuluan, tahap pembinaan lanjutan, tahap asimilasi dan tahap integrasi. LPKA wajib menyelenggarakan pendidikan wajib sembilan tahun.

Pembinaan terdapat 3 (tiga) jenis pembinaan yaitu, pembinaan mental, pembinaan sosial dan pembinaan keterampilan (Hizkia Brayen Lumowa, 2017). Berdasarkan Pedoman perlakukan anak di LPKA, terdapat tiga jenis pembinaan yaitu:

1. Pembinaan kepribadian Pembinaan ini terdiri dari pembinaan kerohanian, kesadaran hukum, jasmani, kesadaran berbangsa dan bernegara serta kegiatan lainnya.

2. Pembinaan keterampilan pembinaan keterampilan terdiri dari kegiatan pembinaan pertanian, peternakan, pertukangan, kesenian danteknologi informasi serta kegiatan lainnya.

3. Pendidikan anak

Pendidikan anakterdiri dari pendidikan formal dan non formal. Pendidikan formal berupa wajib belajar 9 (sembilan) tahun, sedangkan pendidikan non formal mencangkup kejar paket seperti kejar paket A setara dengan SD, kejar paket B setara SMP, dan kejar paket C setara dengan SMA. Berdasarkan UU No. 20 Tahun 2003, pendidikan formal yaitu jenjang pendidikan dasar, menengah dan tinggi; pendidikan informal dan nonformal.

\subsection{Implementasi Hak Pendidikan di LPKA Kutoarjo}

Hak pendidikan untuk anak pidana dalam LPKA masuk dalam proses pembinaan. Berdasarkan pedoman, terdapat tiga jenis pembinaan yaitu:

1. Pembinaan kepribadian Pembinaan ini terdiri dari pembinaan kerohanian, kesadara hukum, jasmani, kesadaran berbangsa dan bernegara serta kegiatan lainnya. 
2. Pembinaan keterampilan pembinaan keterampilan terdiri dari kegiatan pembinaan pertanian, peternakan, pertukangan, kesenian dan teknologi informasi serta kegiatan lainnya.

3. Pendidikan anak

Pendidikan anak terdiri dari pendidikan formal dan non formal. Pendidikan formal berupa wajib belajar 9 (sembilan) tahun, sedangkan pendidikan non formal mencangkup kejar paket seperti kejar paket A setara dengan SD, kejar paket B setara SMP, dan kejar paket C setara dengan SMA.

Pada LPKA Klas 1 Kutoarjo, pembinaannya berupa, Pembinaan kepribadian Pembinaan kepribadian di LPKA Klas 1 Kutoarjo berupa, pembinaan kesadaran berbangsa dan bernegara, kerohanian, kesadaran hukum. Pembinaan kesadaran berbangsa dan bernegara dilakukan untuk membentuk karakter bela negara. Pembinaan ini dilakukan dengan mengundang Komando Rayon Militer (Koramil) 05 Kutoarjo. Selain pelatihan, pembentukan karakter bela negara diwujudkan dengan rutin diadakannya upacara peringatan hari-hari nasional seperti hari kesadaran nasional, sebagai berikut :

1. Kegiatan pembinaan kerohanian berupa pengajian, peringatan hari besar keagamaan, belajar musik hadroh. Pengajian dilakukan rutin yang diadakan melalui kerjasama dengan kementerian agama Kabupaten Purworejo.

2. Pembinaan keterampilan di LPKA Klas 1 Kutoarjo, pembinaan ini termasuk dalam pembinaan kemandirian. Pembinaan keterampilan diisi dengan pembuatan kerajinan tangan boneka pemasyarakatan, gantungan kunci, tempat tisu, tempat pensil dan tas. Selain kerajinan tangan, terdapat pembinaan lainnya dibidang pertanian dan perikanan. Pembinaan ini dilakukan melalui kerjasama dengan Dinas pertanian, kelautan dan perikanan Kabupaten Purworejo. Bentuk kerjasama antara lain dengan diadakannya pelatihan tentang budidaya air tawar dan pembuatan pakan pelet.

3. Pendidikan anak

Pendidikan anak di LPKA Klas 1 Kutoarjo menggunakan pendidikan non formil berupa kejar paket melalui kerjasama dengan Pusat Kegiatan Belajar Masyarakat (PKBM) Tunas Mekar dibawah pengawasan Dinas Pendidikan dan Olahraga Kabupaten Purworejo. PKBM ini mempunyai izin operasional SK No. 421.9/4449/2018, Akta Notaris No. 1 Tahun 2011. PKBM ini terdiri dari: 
a. Kejar Paket A setara SD/MI

b. Kejar Paket B setara SMP/MTs

c. Kejar Paket C setara SMA/MA

Pembinaan tersebut diatas dilaksanakan mulai tahap pembinaan dimulai yaitu tahap pembinaan awal setelah anak pidana selesai melakukan registrasi dan serangkaian proses pada tahap pembinaan awal. Pembinaan anak pidana di LPKA terbagi menjadi tiga tahapan yaitu :

1. Tahap Pembinaan Awal

Tahap ini dilakukan saat masuk di LPKA sampai 1/3 masa pidana. Pada tahap ini dilakukan registrasi seperti penerimaan, pendaftaran dan penempatan serta pengenalan lingkungan. Langkah-langkahnya sebagai berikut:
a. Penelitian Kemasyarakatan dan Asesmen
b. Klasifikasi (Penempatan dan Intensivitas Pengawasan)
c. Perencanaan Program
d. Sidang Tim Pengamat Pemasyarakatan
e. Pelaksanaan Program Pembinaan
f. Pengasuh Pemasyarakatan
g. Pelaporan Pelaksanaan Program pembinaan
h. Pengawasan program pembinaan anak

2. Tahap Pembinaan Lanjutan Tahap ini mulai dilakukan pembauran yang biasa disebut dengan asimilasi. Asimilasi dilakukan mulai dari 1/3 sampai $1 / 2$ masa pidana. Asimilasi ada 2 (dua) yaitu asimilasi dalam dan asimilasi luar. Asimilasi dalam adalah kegiatan pembauran anak pidana dengan masyarakat luar yang dilakukan di dalam LKPA, sedangkan asimilasi luar adalah kegiatan pembauran anak pidana dengan masyarakat luar yang dilakukan di luar LPKA. Asimilasi ini dilakukan 3 jam perhari.

3. Tahap Pembinaan Akhir

Tahap ini adalah tahap penyerahan anak pidana ke Bapas. Hal ini dilakukan pada $1 / 2$ sampai akhir masa pidana. Pembinaan anak pidana dilanjutkan oleh Bapas. Dari tahapan tersebut, proses pemberian hak pendidikan anak pidana atau pemberian pembinaan diberikan pada tahap awal setelah menyelesaikan beberapa proses pendataan atau dapat disebut dengan registrasi. 


\section{KESIMPULAN}

Hak pendidikan untuk anak pidana di LPKA Kutoarjo diterapkan dalam tahapan pembinaan awal. Setelah dilakukan pendaftaran dan mengetahui asal usul anak pidana maka dapat diberikan hak pendidikan. bentuk pemberian hak pendidikan untuk anak pidana dibagi menjadi tiga yaitu Pembinaan kepribadian berupa, pembinaan kesadaran berbangsa dan bernegara seperti peringatan hari-hari besar nasional, kerohanian seperti pengajian, kesadaran hukum seperti anti narkoba; Pembinaan keterampilan diisi dengan pembuatan kerajinan tangan, pertanian dan perikanan seperti beternak ikan lele. Dan yang terakhir adalah pendidikan anak yaitu pendidikan formal yaitu kejar paket $\mathrm{A}$, B, dan C.

Proses pemberian hak pendidikan sesuai dengan pedoman pemberlakukan anak di LPKA. Hak pendidikan diberikan pada tahap pembinaan awal setelah pendaftaran. Hak pendidikan merupakan bagian dari pembinaan. Jika hak pendidikan diberikan secepat mungkin maka pembinaan lebih cepat dilaksanakan dan tujuan pemasyarakatan akan lebih cepat terwujud.

\section{DAFTAR PUSTAKA}

Alden Juniedy Simanjuntak, Anyang, T., \& Simamora, S. (2013). Perlindungan Hukum Terhadap Anak Yang Menjalani Pidana Penjara Di Lembaga Pemasyarakatan Anak Kelas IIB Pontianak. Jurnal Nestor Magister Hukum, 2(2).

Budijanto, O. W. (2013). Pemenuhan Hak Pendidikan Bagi Anak Didik Pemasyarakatan Di Lembaga Pembinaan Khusus Anak. Jurnal Ilmiah Kebijakan Hukum, 7(1), 62-73.

Gandhung Wahyu Febrianto Nugroho. (2018). Perlindungan Hak-Hak Anak

Dalam Proses Pembinaan Di Lembaga Pembinaan Khusus Anak Kelas I Kutoarjo. Recidive, 7(3), 262-274.

Halili. (2015). Hak Asasi Manusia: Dari Teori ke Pedagogi, Universitas Negeri Yogyakarta.

Hartono. (2019). Konsep Pembinaan Anak Dalam Lembaga Pembinaan Khusus Anak (LPKA) Dalam Perspektif Hak Asasi Manusia. Yuriska: Jurnal Ilmiah Hukum, 11(1), 74-96.

Hasibuan, K. A., Marlina, Putra, M. E., \& Ikhsan, E. (2016). Perlindungan Hukum Bagi Anak Pelaku Tindak Pidana (Studi Putusan Pengadilan Negeri Medan Nomor: 27/Pid.Sus-Anak/2014/PN.Mdn). USU Law Journal, 4(2), 177-191. 
Hizkia Brayen Lumowa. (2017). Hak Pendidikan Anak Narapidana Ditinjau dari Undang-Undang Nomor 35 Tahun 2014 tentang Perlindungan Anak. Jurnal Lex Privatum, V(1), 137-145.

Maidin Gultom. (2008). Perlindungan Hukum Terhadap Anak dalam Sistem Peradilan Anak di Indonesia. PT. Rafika Aditama.

Ni Ketut Sri Utari, dkk. (2016). Buku Ajar Hukum Hak Asasi Manusia, Fakultas Hukum Universitas Udayana.

Septianita, H. (2018). Keadilan Restoratif Dalam Putusan Pidana Anak. Jurnal Yudisia, 11(2), 193-208. https://doi.org/10.1111/1467-9604.00254

Setya Wahyudi. (2011). Implementasi Ide Diversi dalam Pembaharuan Sistem Peradilan Pidana Anaka di Indonesia. Genta Publishing.

Sofi Artnisa Siddiq. (2015). Pemenuhan Hak Narapidana Anak dalam Mendapatkan Pendidikan dan Pelatihan. Jurnal Pandecta, 10(1).

Syaiful Sagala. (2003). Konsep dan Makna Pembelajaran untuk Membantu Memecahkan Problematika Belajar dan Mengajar. Alfabeta.

Tatik Mei Widari. (2012). Pemenuhan Hak Pendidikan Anak Didik Pemasyarakatan Di Lembaga Pemasyarakatan Anak. DIH, Jurnal Ilmu Hukum, 8(15), 28-27.

Tatilu, S. S. (2015). Pemenuhan Hak Pendidikan Anak Dalam Masa Pemidanaan Anak. Lex Administratum, III(2), 57-62.

Wagiati Soetodjo. (2010). Hukum Pidana Anak. Refika Aditama. 